\title{
Evaluation of Functional, Pasting and Sensory Properties of Composite Flour Food Formulated from Blends of Maize (Zea-May), Melon Seed, (Citrullus Vulgaris schrad), Carrot (Darcus Carota L) and Crayfish (Evastacus SPP) Flour
}

\author{
Suleiman Mohammed, Jimah Abdulrahman \& Adejumo Patricia \\ Department of Food Technology, Auchi Polytechnic, Auchi
}

\begin{abstract}
This study was designed to evaluate the functional, pasting and sensory properties of composite flour foods formulated from blends of maize, melon seed, carrot and crayfish flour. The maize flour was blended with melon flour, carrot and crayfish flour in the ratio of 100:0:0:0, 80:10:5:5, 70:15:10:5, 60:20:15:5 and 50:30:10:10 and used to formulate composite flour food samples. The composite flour foods produced where evaluate for functional properties, pasting and sensory properties using standard methods: The functional properties of the samples showed that the bulk density, water absorption capacity, emulsification capacity, solubility capacity, swelling capacity, foaming capacity and oil absorption capacity decreases as the substitution of maize with melon, carrot and crayfish flours increases, $0.86 \pm 0.03-0.71 \pm 0.01,2.42 \pm 0.02-2.36 \pm 0.02,4.83 \pm 0.03-4.26 \pm 0.03$, $06.4 \pm 0.02-52 \pm 0.02,92.57 \pm 0.06-86.77 \pm 0.06,3.23 \pm 0.02-2.63 \pm 0.02,38.56 \pm 0.04-29.34 \pm 0.03$ and $2.52 \pm 0.03-$ $1.62 \pm 0.02$ respectively. The control sample had the highest gelation temperature $(92.57 \pm 0.66)$. The pasting properties of the sample also shows that the peak viscosity, breakdown viscosity, setback viscosity final viscosity, trough viscosity and initial viscosity decrease with the increase in substitution with melon, carrot and crayfish flours. But the control sample (A) has the highest peak viscosity, breakdown, set back, final viscosity, trough and initial viscosity respectively. The sensory scores showed that the colour, taste, flavour and texture of the control sample had better consumer sensory attributes, it was significant $(\mathrm{P}<0.05)$ lower in the other nutrients compared to the formulated samples with the exception of carbohydrate.
\end{abstract}

DOI: $10.7176 / \mathrm{JNSR} / 13-4-03$

Publication date: February $28^{\text {th }} 2022$

\section{Introduction}

Malnutrition is a major health problem in developing countries with under nutrition and micro nutrients deficiencies as the leading risk factors for diseases and death (Barber et al., 2017). Currently about 184 million people or $36.0 \%$ of the population in sub-Saharan Africa are chronically hungry (FAO, 2001). In infants and young children according to WHO (2009); It is associated with deficiencies in protein and calories leading to endemic protein malnutrition with its health challenges. Echendu et al. (2004) reported that it decreases intelligence, educability, disease resistance, productivity and activity; such that the physical activity of an individual is impaired to a point where he or she can no longer maintain adequate performance of growth, resisting and recovering from disease, pregnancy, lactation and physical work (Guerrera et al., 2009). The nourishment a baby needs for the first six months of life is provided by human milk, immediately an infant is aged six months there is need to introduce complimentary foods into the diet of a baby to improve the nutrition, growth and development from 6 months to 24 months (Okoye and Ene, 2018). Traditional composite flour foods usually gruel in Nigeria are mainly unsupplimented porridges produced from maize, sorghum or millet prepared separately, deficient in some nutrients which is used to feed infants (Ige, 2017). The prepared gruel due to their high viscosity on cooling, large quantity of water is added during preparation to obtain the right consistency which made it difficult for young children to fulfill their energy and nutrient requirements (Kikafunda et al., 2006). In order to ensure the right transition from breast feeding to the full use of family foods, prevent infant malnutrition and its associated health problems in developing countries; composite flour food should be produced from locally nutrient dense crops that are available and affordable in the affected communities of interest (Okoye et al., 2010; Bolarinwa et al., 2016).

Maize (Zea mays) in term of cultivation areas and total production, is the most important cereal in the world after wheat and rice. It is a staple food crop grown in diverse environments, prepared and consumed by people with varying food preferences and socioeconomic background in Africa (Bello and Udo, 2018). Its economic values increased through the development of technologies employed to process it into value added products hence promoting its production and consumption. It is a rich source of carbohydrates, vitamins, proteins and minerals and has a horny endosperm and more carotenoids which are the source of yellow colour in maize (Junpatiw et al., 2013; Bello and Oluwalana, 2017).

Melon (Citrullus vulgaris) is a member of the cucurbitaceous family; it is a large plant family which includes many economic species such as melon, various gourds, pumpkins and cucumbers (Oyeleke et al., 2012). 
It is grown widely in the tropics and its seeds popularly known as "egusi" in Nigeria (Akusu and Kiin-Kabari, 2015). Melon seed is an excellent vegetable protein, cultivated in West Africa and contains essential vitamins and minerals in proper proportion. It complements starch and grain diet in African homes and is ideal for battling nutritional debilitations (Okorie, 2018; Achigan-Dako et al., 2018; Fomekong et al., 2008).

Carrot (Dacus Carota) is one of the important nutritious root vegetables grown throughout the world. It is an excellent source of phytonutrients such as phenolics, polyacetylenes and carotenoids (Hansen et al.,2003). Carotenoids are potent antioxidants present in carrots which help to neutralize the effect of free radicals (Ibidapo et al., 2012). According to Dias (2012) reports have shown that they have inhibitory mutagenesis activity thus, contributing to decrease risk of some cancers.

In Nigeria, Crayfish is one of the cheapest sources of animal protein although generally, fish flesh contains mainly water, protein, fat with traces of carbohydrates, amino acids and other non- protein nitrogenous extractives, various minerals and vitamins (Onabanjo et al., 2009). The fibres of crayfish are shorter than those of other meat products hence, they are easier to digest.

The production of porridges from the blends of maize, melon, carrot and crayfish flour will not only help to improve the macro and micro nutrient contents of the food products but will also enhance the nutrients intake of infants, young children and adults, thereby preventing the problem of protein-energy and micronutrients malnutrition in developing countries of the world. Hence this present study was undertaken to evaluate the proximate, pasting and sensory properties of composite flour foods prepared from blends of maize, melon, carrot and crayfish.

\section{MATERIALS AND METHOD}

Source of Materials

Yellow maize grain, melon seed, carrot, Cray fish, container and air tight nylon were purchased from Uchi market in Etsako local government Area of Edo state, Nigeria

\section{Materials}

Maize, melon seed, carrot, crayfish, muslin cloth (sieve), jute bag, bowls, knifes, tray, bucket and container for packaging

\section{Methods}

\section{Preparation of Fermented Maize Flour}

The method of fermentation of maize was done according to Baningo and Akpapunam (1999) and Omueti et.al, (2009) with modification for the production Ogi flour. maize grains were sorted to remove stones and foreign bodies, washed and steeped in clean water for two days (48 hours) in a 20 litre bucket and convered. The contents was allowed to ferment at room temperature for 48 hours. The steeped water was changed with fresh water after each day. The steeped water was decanted and the fermented maize grains was wet milled with hydraulic milling machine. The slurries were sieved through a fine sieve (muslin cloth) with excess water and the shaft were discarded, the resultant slurry was left to ferment in the water for 12 hours. Thereafter excess water was decanted. The slurry was dewatered using a jute bag and the cake obtained was dried. The dried sample passed through the hydraulic milling machine a second time after milling it was allowed to cool and sieve to obtained fine particles The "Ogi" flour was then stored in air tight container for further used.

\section{Preparation of Melon Flour}

The melon seeds was clean manually through physical sorting to remove dirt and other foreign particles that could adhere to it, it was then washed in clean water and sun dried for about 2-3days, and later oven dried for 2 day at $80^{\circ} \mathrm{C}$ for 5 hours. After drying, it was milled into fine smooth particles and later sieved to obtained the powdered.

\section{Preparation of Carrot Flour}

The method used was according to Obinna-Echem et.al, (2015) with slight modification for the production of carrot flour. Fresh carrot was washed and the outer layer scraped or peeled. The peeled carrot was sliced or diced into a mixture of water with sodium Metabisulphite $\left(\mathrm{Na}_{2} \mathrm{~S}_{2}\right)$ to prevent browning. The diced carrot was then filtered from the water and dried in the sun for 2-3days. The dried carrot was milled with hydraulic milling machine to obtained carrot flour and after milling it was cooled and then sieved to fine flour and finally packed in an airtight container for further use

\section{Preparation of Cray Fish Flour}

Cray fish was clean manually by physical sorting to remove dirt and lint. After that, it was then washed with clean water followed by drying under the sun for 2-3 days after drying it was milled into flour using hydraulic 
milling machine, and followed by sieving to obtain crayfish flour.

FUNCTIONAL PROPERTIES: The method described by AOAC (2006) was used to determine Bulk Density, Water Absorption Capacity, Emulsion Capacity, Least Gelation Temperature, Oil Absorption Capacity, Foam Capacity, Solubility and $\mathrm{pH}$ was determined using digital $\mathrm{pH}$ meter.

PASTING PROPERTIES: Pasting properties of the composite flour foods were determined using a rapid viscous analyzed (Newport scientific, RVA super 3, Switzerland) as described by AACC, (2001). Peak viscosity, trough viscosity, breakdown viscosity, final viscosity, setback viscosity, peak time.

SENSORY PROPERTIES: The sensory scores of the gruels prepared from both the control and the formulated sample showed significant $(\mathrm{P}<0.05)$ different in colour, taste, aroma, texture and general acceptability.

STATISTICAL ANALYSIS: The data generated were statistically analyzed for means and standard deviation and analysis of variance (ANOVA) was used to test the level of significance. Duncan's new multiple range test was used to compare and separate means significance.

\section{RESULT}

Functional Properties of Composite flour food Formulation

\begin{tabular}{|c|c|c|c|c|c|c|c|c|c|}
\hline $\begin{array}{l}\text { Samples } \\
\text { ID }\end{array}$ & $\begin{array}{l}\text { \% substitution } \\
\text { MF:Mf;CFF:CF }\end{array}$ & $\begin{array}{l}\text { Bulk } \\
\text { density } \\
\text { (g/cm3) }\end{array}$ & $\begin{array}{l}\text { Water } \\
\text { absorption } \\
\text { capacity } \\
\text { (m3) }\end{array}$ & $\begin{array}{l}\text { Emulsification } \\
(\%)\end{array}$ & $\begin{array}{l}\text { Water } \\
\text { solubility }\end{array}$ & $\begin{array}{l}\text { Galeton } \\
\operatorname{tamp}\left({ }^{\circ} \mathrm{c}\right)\end{array}$ & $\begin{array}{l}\text { Swelling } \\
\text { capacity } \\
\text { (g/g) }\end{array}$ & $\begin{array}{l}\text { Foaming } \\
\text { capacity } \\
(\%)\end{array}$ & $\begin{array}{l}\text { Oil } \\
\text { absorption } \\
\text { capacity } \\
\left(\mathbf{M}^{3}\right)\end{array}$ \\
\hline $\mathbf{A}$ & 100:0:0:0 & $0.86^{\mathrm{a}} \pm 0.03$ & $2.42^{\mathrm{a}} \pm 0.02$ & $4.83^{\mathrm{a}} \pm 0.03$ & $0.64^{\mathrm{a}} \pm 0.02$ & $92.57^{\mathrm{a}} \pm 0.06$ & $3.23^{\mathrm{a}} \pm 0.02$ & $38.56^{\mathrm{a}} \pm 0.04$ & $2.52^{\mathrm{a}} \pm 0.03$ \\
\hline B & $80: 10: 5: 5$ & $0.72^{\mathrm{c}} \pm 0.01$ & $2.21^{\mathrm{d}} \pm 0.02$ & $4.70^{b} \pm 0.03$ & $0.53^{\mathrm{bc}} \pm 0.01$ & $85.47^{\mathrm{c}} \pm 0.06$ & $2.95^{b} \pm 0.01$ & $25.32^{\mathrm{c}} \pm 0.04$ & $1.77^{\mathrm{b}} \pm 0.03$ \\
\hline $\mathrm{C}$ & $70: 15: 10: 5$ & $0.77^{b} \pm 0.01$ & $2.33^{b} \pm 0.03$ & $4.73^{b} \pm 0.02$ & $0.25^{c} \pm 0.02$ & $85.40^{\mathrm{c}} \pm 0.00$ & $2.71^{c} \pm 0.02$ & $19.24^{b} \pm 0.03$ & $1.72^{c} \pm 0.02$ \\
\hline D & $60: 20: 15: 5$ & $0.78^{b} \pm 0.01$ & $2.25^{c} \pm 0.01$ & $4.16^{\mathrm{d}} \pm 0.03$ & $0.56^{b} \pm 0.02$ & $83.33^{\mathrm{d}} \pm 0.06$ & $2.63^{\mathrm{d}} \pm 0.04$ & $18.90^{\mathrm{d}} \pm 0.03$ & $1.62^{\mathrm{d}} \pm 0.02$ \\
\hline $\mathbf{E}$ & $50: 30: 10: 10$ & $0.71^{\mathrm{c}} \pm 0.01$ & $2.36^{\mathrm{b}} \pm 0.02$ & $4.26^{\mathrm{c}} \pm 0.03$ & $0.52^{\mathrm{a}} \pm 0.02$ & $86.77^{b} \pm 0.06$ & $2.63^{\mathrm{d}} \pm 0.02$ & $29.34^{b} \pm 0.03$ & $1.62^{\mathrm{d}} \pm 0.02$ \\
\hline
\end{tabular}

Sample $\mathrm{A}=100 \% \mathrm{MF}$, Sample B $=80 \% \mathrm{MF}, 10 \% \mathrm{Mf}, 5 \% \mathrm{CFF}$ and $5 \% \mathrm{CF}$, Sample C $=70 \% \mathrm{MF}, 15 \% \mathrm{Mf}$, $10 \% \mathrm{CFF}$ and $5 \% \mathrm{CF}$, Sample D $=60 \% \mathrm{MF}, 20 \% \mathrm{Mf}, 15 \% \mathrm{CFF}$ and $5 \% \mathrm{CF}$, Sample E $=50 \% \mathrm{MF}, 30 \% \mathrm{Mf}$, $10 \% \mathrm{CFF}$ and $10 \% \mathrm{CF}$

Value are mean \pm standard deviation of triplicate determinations

Means in the same column with different superscripts are significantly different $(\mathrm{P}<0.05)$

MF: Fermented maize flour, Mf: melon flour, CFF: crayfish flour, CF: carrot flour

\section{Pasting Properties of Composite flour food formulation}

\begin{tabular}{|l|l|l|l|l|l|l|l|}
\hline $\begin{array}{l}\text { Samples } \\
\text { ID }\end{array}$ & $\begin{array}{l}\text { \% substitution } \\
\text { MF:Mf;CFF:CF }\end{array}$ & Peak viscosity & Breakdown & Setback & Final viscosity & $\begin{array}{l}\text { Trough } \\
\text { viscosity }\end{array}$ \\
\hline A & $100: 0: 0: 0$ & $169.82^{\mathrm{c}} \pm 0.02$ & $84.54^{\mathrm{b}} \pm 0.03$ & $4.78^{\mathrm{c}} \pm 0.03$ & $143.63^{\mathrm{a}} \pm 0.12$ & $99.34^{\mathrm{a}} \pm 0.05$ \\
\hline B & $80: 10: 5: 5$ & $171.14^{\mathrm{b}} \pm 0.03$ & $68.41^{\mathrm{b}} \pm 0.05$ & $76.37^{\mathrm{c}} \pm 0.08$ & $139.46^{\mathrm{b}} \pm 0.09$ & $96.10^{\mathrm{b}} \pm 2.86$ \\
\hline C & $70: 15: 10: 5$ & $176.67^{\mathrm{a}} \pm 0.04$ & $67.91^{\mathrm{a}} \pm 0.01$ & $87.21^{\mathrm{a}} \pm 0.02$ & $134.09^{\mathrm{b}} \pm 0.08$ & $87.47^{\mathrm{a}} \pm 0.04$ \\
\hline D & $60: 20: 15: 5$ & $148.32^{\mathrm{c}} \pm 0.02$ & $57.46^{\mathrm{d}} \pm 0.01$ & $79.43^{\mathrm{c}} \pm 0.05$ & $137.36^{\mathrm{c}} \pm 0.03$ & $85.23^{\mathrm{c}} \pm 0.04$ \\
\hline $\mathbf{E}$ & $50: 30: 10: 10$ & $162.63^{\mathrm{d}} \pm 0.02$ & $49.32^{\mathrm{c}} \pm 0.02$ & $77.59^{\mathrm{d}} \pm 0.08$ & $130^{\mathrm{c}} \pm 0.04$ & $141.06^{\mathrm{a}} \pm 0.06$ \\
\hline
\end{tabular}

Sample A $=100 \% \mathrm{MF}$, Sample B $=80 \% \mathrm{MF}, 10 \% \mathrm{Mf}, 5 \% \mathrm{CFF}$ and $5 \% \mathrm{CF}$, Sample C $=70 \% \mathrm{MF}, 15 \% \mathrm{Mf}$, $10 \% \mathrm{CFF}$ and $5 \% \mathrm{CF}$, Sample D $=60 \% \mathrm{MF}, 20 \% \mathrm{Mf}, 15 \% \mathrm{CFF}$ and $5 \% \mathrm{CF}$, Sample E $=50 \% \mathrm{MF}, 30 \% \mathrm{Mf}$, $10 \% \mathrm{CFF}$ and $10 \% \mathrm{CF}$

Value are mean \pm standard deviation of triplicate determinations

Means in the same column with different superscripts are significantly different $(\mathrm{P}<0.05)$

MF: Fermented maize flour, Mf: melon flour, CFF: crayfish flour, CF: carrot flour

Sensory evaluation of composite flour food
\begin{tabular}{|l|l|l|l|l|l|l|}
\hline Samples & $\begin{array}{l}\text { \% substitution } \\
\text { MF:Mf;CFF:CF }\end{array}$ & Colour & Texture & Taste & Aroma & $\begin{array}{l}\text { General } \\
\text { acceptability }\end{array}$ \\
\hline A & $100: 0: 0: 0$ & $8.30^{\mathrm{a}} \pm 0.82$ & $7.80^{\mathrm{a}} \pm 1.32$ & $7.70^{\mathrm{a}} \pm 1.76$ & $7.90^{\mathrm{a}} \pm 1.52$ & $8.30^{\mathrm{a}} \pm 0.67$ \\
\hline B & $80: 10: 5: 5$ & $7.90^{\mathrm{a}} \pm 0.86$ & $7.30^{\mathrm{ab}} \pm 1.42$ & $7.20^{\mathrm{ab}} \pm 1.32$ & $7.70^{\mathrm{a}} \pm 1.50$ & $7.50^{\mathrm{ab}_{ \pm}} \pm 1.18$ \\
\hline C & $70: 15: 10: 5$ & $7.20^{\mathrm{a}} \pm 1.62$ & $7.40^{\mathrm{ab}} \pm 0.70$ & $6.70^{\mathrm{ab}} \pm 1.06$ & $7.30^{\mathrm{a}} \pm 1.25$ & $7.10^{\mathrm{abc}_{ \pm}} \pm 1.10$ \\
\hline D & $60: 20: 15: 5$ & $7.00^{\mathrm{a}} \pm 1.50$ & $7.00^{\mathrm{ab}} \pm 0.94$ & $5.40^{\mathrm{c}} \pm 1.58$ & $6.60^{\mathrm{a}} \pm 1.65$ & $6.40^{\mathrm{bc}_{ \pm}} \pm 1.51$ \\
\hline E & $50: 30: 10: 10$ & $5.20^{\mathrm{b}} \pm 1.87$ & $6.50^{\mathrm{b}} \pm 1.27$ & $5.90^{\mathrm{bc}} \pm 1.45$ & $6.80^{\mathrm{a}} \pm 1.56$ & $6.20^{\mathrm{c}} \pm 1.69$ \\
\hline
\end{tabular}

Sample A $=100 \% \mathrm{MF}$, Sample B $=80 \% \mathrm{MF}, 10 \% \mathrm{Mf}$, 5\%CFF and 5\%CF, Sample C $=70 \% \mathrm{MF}, 15 \% \mathrm{Mf}$, $10 \% \mathrm{CFF}$ and $5 \% \mathrm{CF}$, Sample D $=60 \% \mathrm{MF}, 20 \% \mathrm{Mf}, 15 \% \mathrm{CFF}$ and 5\%CF, Sample E $=50 \% \mathrm{MF}, 30 \% \mathrm{Mf}$, $10 \% \mathrm{CFF}$ and $10 \% \mathrm{CF}$

Value are mean \pm standard deviation of triplicate determinations

\section{Discussion}

Functional Properties of Composite flour food Formulation

The fundamental characteristic of the composite flour food formulation are presented in table 4.2. The bulk 
density of the composite flour food varies from 0.86 to $0.71 \mathrm{mg} / 100 \mathrm{~g}$ with the control sample $(100 \%$ fermented maize flour) had the highest value $(0.86 \mathrm{mg} / 100)$ and formulations with $30 \%$ melon, $10 \%$ crayfish and $10 \%$ carrot flours blends with the least value $(0.71 \mathrm{mg} / \mathrm{cm} 3)$.

The value is significant $(\mathrm{P}<0.05)$ from each other. The lower the bulk density value, the higher the amount of the flour particles that can stay together and thus increasing energy content which could not be denied form such diets (Onimawo and Egbekun, 1998). According to Nnam (2001), low bulk density has nutritional and economic significance as more of the product can be eaten resulting in high energy and nutritional density. Water absorption capacity of the composite flour food ranged from 2.42 to $2.36 \mathrm{~m} 3$ with the control (100\%) fermented maize flour having the highest value $(2.42 \mathrm{~m} 3)$ and formulation with $10 \%$ melon, $5 \%$ crayfish and $5 \%$ carrot flour substitution with the least value $(2.21 \mathrm{~cm} 3)$. This significant $(\mathrm{P}<0.05)$ decrease in the water absorption is as a result of the increase in the substitution of melon, crayfish and carrot flours in the blend, and this shows that maize flours requires more water than crayfish and carrot flours. Emulsification capacity of the composite flour foods ranged from 4.83 to $4.26 \%$ with the control sample (100\% fermented maize flour) having the highest value (4.83\%) and the formulation with $20 \%$ melon, $15 \%$ crayfish and $5 \%$ carrot flours substitution with the least value $(4.16 \%)$. The emulsification value is significant $(\mathrm{p}<0.05)$ from each other, the emulsification properties are influenced by many factors which include solubility and $\mathrm{p}^{\mathrm{H}}$. The varying emulsifying and stabilization capacity may be due to different composition and stress to which these products are subjected (Nelson and Cox, 2000). Oyarekua and Adeyeye (2009) reported that high value of emulsion capacity acts as flavour retainer and enhance the mouth fees and the taste of the food. Water solubility of the composite flour foods sample ranged from 0.64 to $0.52 \mathrm{~m} 3$ with the control sample $(100 \%$ fermented maize flour) having the highest value $(0.64 \mathrm{~m} 3)$ while the formulation with $15 \%$ melon, $10 \%$ crayfish and $5 \%$ carrot flour substitution had the least value $(0.25 \mathrm{~cm} 3)$. There is significant $(\mathrm{P}<0.05)$ in the samples however, composite flour food do not requires high solubility as the food would absorb more water and have less solid resulting in low nutrient density for the child. Gelation temperature of the composite flour food ranged from 92.57 to $86.77^{\circ} \mathrm{c}$, with the control $\left(100 \%\right.$ fermented maize flour) having the highest value $\left(92.57^{\circ} \mathrm{c}\right)$ while formulation with $20 \%$ melon, $15 \%$ crayfish and $5 \%$ carrot flours substitution had the least value $\left(83.33^{\circ} \mathrm{c}\right)$ the decreased in the gelation temperature observed in this study is attributed to the increase in the melon, crayfish and carrot flours in the blends. The gelatinization process is a property of the starch granule found in cereals, gelation is of important functional properties of food materials which affect texture. Swelling capacity of the composite flour food varied from 3.23 to $2.63 \mathrm{~g} / \mathrm{g}$. with the control $(100 \%$ fermented maize flour) having the highest value $(3.23 \mathrm{~g} / \mathrm{g})$. The decrease in swelling capacity is a as result of the increase in melon, carrot and crayfish flour in the blends foaming capacity of the composite flour food ranged from 38.56 to $29.39 \%$ with the control sample (100\% fermented maize flour) having the highest value (38.56). The foaming capacity decrease in the formulations as there is increase in melon, carrot and crayfish flour in the blends and this shows that the increase in protein content of the composite flour foods also led to increase in the foaming capacity. Oil absorption capacity of the composite flour food ranged from 2.52 to $1.62 \mathrm{~m} 3$. The value is significant $(\mathrm{P}<0.05)$ from each other with the control (100\% fermented maize flour) having the highest value $(2.53 \mathrm{~m} 3)$. The oil absorption was decreasing with decrease in maize flour and increase in melon, carrot and crayfish flours in the blends. Melon crayfish and carrot has little oil compare to maize flour, and the oil with plant materials acts as fat in the composite flour food.

\section{Pasting Properties of Composite flour food formulations}

The pasting characteristics of composite flour foods samples are presented in Table 4.4 the peak viscosity of the complimentary food samples ranged from 169.82 to $162.63 \mathrm{RVU}$ with the formulation with $15 \%$ melon, $10 \%$ crayfish and 5\% carrot had the highest value (176.67 RVU) and the control samples (100\% fermented maize flour) had the value (169.82 RVU) close to the highest. While the formulation with $20 \%$ melon, $15 \%$ crayfish and $2 \%$ carrot had the least value (148.32 RVU). The observed increased in the peak viscosity of the samples could be attributed to the addition of melon, crayfish and carrot flours in the be attributed to the addition of melon, crayfish and carrot flours in the blends which do not contain degraded starch. The increase in the peak viscosity of composite flour foods is generally not advantageous because the gruels prepared from them would not be watery and more solid will not be added, hence this will discourage age the addition of more nutrients and energy constituents which are much better for growing children (Onweluzo and Nwabugwu, 2009). The breakdown viscosity of the composite flour foods samples ranged from 73.64 to 49.32 RVU with the control sample (100\% fermented maize four) having the highest (73.64 RVU) breakdown viscosity while the formulations with $30 \%$ melon, $10 \%$ crayfish and $10 \%$ carrot substitution had the least (49.32 RVU) breakdown viscosity. The breakdown viscosity is essentially a measure of the degree of paste stability or starch granule disintegration during heating (AACC, 2001). The sample with 30\% melon, 10\%crayfish and $10 \%$ carrot substitution which had relatively low breakdown viscosity (49.32 RVU) will have a more stable paste during heating than the control sample which had the highest breakdown viscosity (73.64 RVU) (Ayo and Ogunsaki, 2013). However, the addition of melon crayfish and carrot flours in the blends tends to generally reduce the 
breakdown viscosity, thereby making the paste more stable during heating. The ability of starch to withstand heating at high temperature and shear stress is an important factor in many process. Elofsson et al, (1997) reported that the formulation of gels by the proteins in foods results from a two-step process involving, first, partial denaturation of individual proteins to allow more access to the reactive side groups within the protein molecules and secondary, aggregation of these proteins by means of reactive side groups into a continuous three dimensional network structure capable of retaining significant amount of water and also exhibiting some structural rigidity. This phenomenon is of great importance in foods since it contributes significantly $(\mathrm{P}<0.05)$ to textural and rheological properties of various foods. The setback viscosity of the complementary food ranges from 84.54 to 77.59 RVU with the control sample (100\% fermented maize flour) having the highest setback viscosity (84.54 RVU) while formulations with $10 \%$ melon, $5 \%$ crayfish and $5 \%$ carrot flour substitution having the least (76.37 RVU). The setback viscosity decreased in the sample with increase in the substitution of melon, carrot and crayfish flour in the blends. The higher the substitution level, the more the retro gradation level during cooling and the higher the staling of the products made from the flour (Adeyemi and Idowu, 1990). A high setback viscosity value is associated with a cohesive paste while a low value is an indication that the paste is not cohesive (Odura et al, 2000).

The phase is commonly descried as the setback region and is related to retrogradation and reordering of starch molecules. The reduction in setback viscosity of the samples is an indication of low rate of starch retro gradation and synergies of gel. The setback viscosity is usually regarded as an index of retrogradation tendency of the paste prepared from a starchy food. (Julanti, et al,. 2005). The final viscosity of the complementary foods ranged from 143.63 to 130 RVU with the control sample (100\% fermented maize flour) having the highest (143.63RVU) final viscosity and the formulation with 30\% melon, $10 \%$ crayfish and 10 carrot flour substitution with the least value (130 RVU). The inclusion of melon carrot and crayfish flours in the formulations was generally observed to cause reduction in the final viscosity. The final viscosity is usually regarded as an indication of stability of the cooked paste (Regaee and Abdel Al, 2006). The trough viscosity in the complementary foods ranged from 99.34 to 86.42 RVU with the control sample ( $100 \%$ fermented maize flour) having the highest value 99.34RVU and formulation with $20 \%$ melon, $15 \%$ crayfish and $5 \%$ carrot flours substitution with the least value (85.27 RVU). The decreased in the through viscosity of the food samples could be attributed to the inclusion of melon, crayfish and carrot flours in the blends. Through is the minimum viscosity which measures the ability of paste to withstand breakdown during cooling (Balarinwa et al, 2015).

Initial viscosity of the complementary foods ranged from 156.17 to 144.19 RVU with the control sample (100\% fermented maize flour) having the highest value (156.17 RVU) and formulation with 15\% melon, $10 \%$ crayfish and 5\% carrot substitution with the least value (141.06 RVU). The decrease in the initial viscosity is attributed to the inclusion of melon, cray fish and carrot flours in the blends. The initial viscosity is usually regarded as an indication of the total time taken by each sample to attain its respective peak viscosity.

\section{Sensory Properties of Composite flour Foods Formulations}

The sensory properties of composite flour food samples are presented in Table 4.6. The sensory scores of the gruels prepared from both the control and the formulated sample showed significant $(\mathrm{P}<0.05)$ different in colour, taste, aroma, texture and general acceptability. The control sample was significantly scored highest compared to all other test samples in the parameter evaluated by the judges. The samples substituted with $10 \%$ melon, $5 \%$ crayfish and $5 \%$ carrot flour had no significant $(\mathrm{P}<0.05)$ in taste and Aroma. The gruel made from $100 \%$ fermented maize flour and those prepared from the sample substituted with 10:5:5 and 15:5 were generally accepted. The increase in the substitution with melon, crayfish and carrot flours resulted in the decrease in the acceptability of the gruels as indicated by the significant $(\mathrm{P}<0.05)$ low value for sample substituted with $30 \%$ melon, $10 \%$ crayfish and $10 \%$ carrot flour. The gruel containing 30\% melon, $10 \%$ crayfish and $10 \%$ carrot flour was reported to have crumbly texture due to increase substitution with melon, crayfish and carrot flours respectively. The Judges described the gruel made from the 10\% melon, 5\% crayfish and 5\% carrot flour substitution as having the best colour, taste, Aroma and general acceptability when compare to the other samples apart from the control. However, the substitution of fermented maize flour with $10 \%$ melon, $5 \%$ crayfish and $5 \%$ carrot flours could be used to produce organoletically acceptable composite flour food product.

\section{Conclusions}

The study evaluates the functional properties, pasting and sensory properties of composite flour food from a blend of fermented maize flour, melon flour, carrot flour and cray fish flour. The formulated composite flour food exhibited final viscosity, setback viscosity and initial viscosity are desirable for composite flour food formulation. Its shows that an acceptable composite flour food is developed from blend of maize flour, melon flour, carrot flour and Cray fish flour. 


\section{References}

AACC, (2001). Approved method of the association of cereal chemist (1 $1^{\text {th }}$ ed, method 61-02-01. Determination of pasting properties on blended flour with the rapid visco analyzer) St Paul, MN: Author.

Achigan-Dako, V., Vodouhe, S. R. and Sangare, A. (2018). "Characterization Morphologique Des Cultivars Locaux De Lagenaria Siceraria (Cucurbitaceae) Collectés Au Bénin Et Au Togo". Belgium Journal of Botany, 141(1):21-38.

Akusu, M.O. and Kiin-Kabari, D.B. (2015). Comparative Studies on the Physicochemical and Sensory Properties of Watermelon (Citrullus lanatus) and Melon (Citrullus vulgaris) Seed Flours Used in "EGUSI" Soup Preparation. Journal of Food Research, 4(5):1-8

Adeyemi, I.A., Idowu, M.A, (1990). Effect of Drum Drying on the Colour, Functional and Pasting Properties of Sweet potato-based Composite flour food. American Journal of Food Science and Technology. Vol. 5 No. 5 , 210-219.

AOAC, (2006) official method of analysis. $15^{\text {th }}$ edition, association of official analytical chemists, Washington, DC.USA. p 1546

Ayo-Omogie, H.N. and Ogunsaki, R. (2013). Assessment of chemical, rheological and sensory properties of fermented maize-cardaba banana composite flour food. International journal of food and nutrition 4, 844850

Barber, L.I., Obinna-Echem, P.C. and Ogburia, E.M. (2017). Proximate composition, micronutrient and sensory properties of composite flour food formulated from fermented maize soya bean and carrots. Sky journal of Food Science, 6(3): 033-039.

Bello, F.A. and Oluwalana, I.B. (2017). Impact of modified atmosphere packaging on nutritive values and sensory qualities of fresh maize (Zea mays L.) under tropical ambient storage condition. International Journal of Nutrition and Food Sciences, 6(1):9-24.

Bello, F.A. and Udo. J.A. (2018). Effect of processing methods on the nutritional composition and functional properties of flours from white and yellow local maize varieties. Journal of Advances in Food Science \& Technology, 5(1):1-7.

Bolarinwa, I.F., Olajide, J.O., Oke, M.O., and Grace, F.O. (2016). Production and quality evaluation of composite flour foods from malted milet, plantain and Soya bean Blends, International Journal of Science and Engineering Research, 7(5): 663-674

Dias, J. S. (2012). Major classes of phytonutriceuticals in vegetables and health benefits: A review. Journal of Nutritional Therapeutics, 1:31-62.

Echendu, C.A.A, Onimawo, I.A. and Somtochi, A. (2004). Production and evaluation of doughnuts and biscuits from maize- pigeon pea blends. Nigerian Journal of Food Science and Technology; 22: 147-153

FAO (2001). Human vitamin and mineral requirements: Report of a joint FAO/WHO expert consultation. Bangkok, Thailand: FAO, Rome, Italy.

Fomekong, A., Messi, J., Kekeunou, S.,Tchuenguem Folou, F. N. and Tamesse, J. L. (2008). "Entomoau Na Of Cucumeropsis Mannii Naudin, its Impact Plant Yield and Some Aspects of the Biology of Dakus Bivitatus (diptera:Tephritidea)", African Journal of Agricultural Research, 3(5):365-370.

Guerrera, M.P., Volpe, S.L. and Mao, J.J. (2009). Therapeutic uses of magnesium. American Family and Physician; 80: 157-162

Hansen, S., Purup, S. and Chritensen, L.P. (2003). Bioactivity of falcarinol and the influence of processing and storage on its content in carrots (Daucus carota). Journal of Science Food Agriculture, 83:1010-1017

Ibidapo, O.P., Ogunji, A.A., Toyin, O.F., Akinyele, O., Efuribe N. (2012). Development and quality evaluation of carrot powder and cowpea flour enriched biscuits. International Journal of Food Science and Biotechnology, 2(3):67-72.

Ige, M. M. (2017). Physicochemical, pasting and sensory characteristics of composite flour foods formulated from plantain, pigeon pea and maize flours. Donnish Journal of Food Science and Technology, 3(2):7- 15.

Julanti, E. Rusmarilin, H. and Ridwansyah, E.Y. (2005). Functional and Rheological properties of composite flour from sweet potato, maize, soya bean and xanthan gum Journal Saudi Society, Agric Science 5, 1-9.

Junpatiw, A., Lertrat, K., Lomthaisong, K and Tangwongchai, R. (2013). Effects of steaming, boiling and frozen storage on carotenoid contents of various sweet corn cultivars. International Food Research Journal, 20(5):2219-2225.

Kikafunda, J.K., Abenakyo, L. and Lukwago, F.B. (2006). Nutritional and sensory properties of high energy/nutrient dense composite flour porridges from germinated maize and roasted beans for childweaning in developing countries: a case for Uganda. Journal of Ecology Food and Nutrition; 45:279-294.

Nelson, D.I. and Cox, M.M. (2000) Lininger principles of Biochemistry Replika Press, PVT ltd, Indian pp. 1170124.

Nnam, N.M. (2001) Chemical, Sensory and Rhetorical properties of porridge from processed sorghum (Sorghum Bicolor) Bambara Groundnut (Vigna Subteranam L. Verde) and sweet potato (Ipomoea batatas) flours. 
Plant food for human nutrition 56:25-264.

Obinna- Echem, P.C, kuri, v, Beal, J (2015). Effect of processing methods on the mineral content of Nigeria fermented infant composite flour food- Akamu. LWT-food science technology, 61:145-151.

Okorie, P.A. (2018). Comparative Study of Properties and Compositions of Three Varieties of Melon Seed Flour in Ebonyi State of Nigeria. International Journal for Research in Emerging Science and Technology, 5(6): 2349-7610.

Okoye, J. I. and Ene, G. I. (2018). Evaluation of nutritional and organoleptic properties of maize-based composite flour foods supplemented with black bean and crayfish flours. Global Advanced Research Journal of Food Science and Technology, 6(1):1-9.

Okoye, J. I., Ezigbo, V. O. and Animalu, I. L. (2010). Development and quality evaluation of weaning foods fortified with African yam bean flour. Continental Journal of Agricultural Science; 4:1-6

Omueti, O, Bolanle O, Olayinka J, Olukayode, A. (2009) functional properties of composite flour food diet developed from soya bean (Glycine max) groundnut (Arrachis hypogeal) and cray fish (macro brachium SPP). Elect. Journal of Environmental Agriculture food chemistry,8(8): 563-573.

Onabanjo O.O. Akinyemi, C.O. and Agbon, C.A. (2009). Characteristics of composite flour foods produced from sorghum, sesame, carrot and crayfish. Journal of Natural Sciences, Engineering and Technology; 8 (1): $71-83$.

Onimawo, A.I. and Egbekun, K.M. (1998) comprehensive food science and Nutrition, Macmillian Press, Ibadan $\operatorname{Pp} 228$.

Onweluzo, J. C. anandd Nwabugwu, C.C. (2009).Fermentation of Millet (Pennisetum americanum) and Pigeon Pea (Cajanus cajan) Seeds for Flour Production: Effects on Composition and Selected Functional Properties. Pakistan Journal of Nutrition. Volume: 8 | Issue: 6 | Page No.: 737-744

Oyarekua, M.A. and Adeyeye, E.I. (2009). Comprehensive evaluation of Nutritional quality, functional properties and Amino acid profile of fermented maize/cowpea ogi as infant composite flour food Asian journal of chemistry and nutrition 1:31:39.

WHO (2009). Proceedings of the WHO, UNICEF WEP UNHCR informal consultation on the management of moderate nutrition in under -5 children, Geneva, October. 2008. Food and Nutrition Bulletin; 30(3): S. 464-474. 